(C) Copyright, Princeton University Press. No part of this book may be distributed, posted, or reproduced in any form by digital or mechanical means without prior written permission of the publisher.

\title{
The Emperors of Banking Have No Clothes
}

I just think that this constant refrain "bankers, bankers, bankers" is just unproductive and unfair. People should just stop doing that.

Jamie Dimon, chief executive officer of JPMorgan Chase, Davos, Switzerland, January 27, 2011

The world has paid with tens of millions of unemployed, who were in no way to blame and who paid for everything. It caused a lot of anger. . . We saw that for the last 10 years, major institutions in which we thought we could trust had done things which had nothing to do with simple common sense.

Nicolas Sarkozy, President of the French Republic, Davos, Switzerland, January 27,2011

- OR THE FIRST YEAR after the financial crisis of 2007-2009, bankers were lying low, mindful of the anger that had been caused by the crisis and by the use of taxpayers' money to bail out banks. ${ }^{1}$ French President Nicolas Sarkozy's response to JPMorgan chief executive officer (CEO) Jamie Dimon in Davos in 2011 resonated widely with the media and the public. ${ }^{2}$

At that time, most bank lobbying went on behind the scenes. Since then, however, the banking lobby has become outspoken again. ${ }^{3}$ As in the years before the crisis, bankers have been lobbying relentlessly and speaking up in public against tighter banking regulation. ${ }^{4}$ Leading bankers present themselves as experts who know and care about what is good for the economy. They are regularly consulted by leading government officials, regulators, and politicians. ${ }^{5}$ Every utterance of a major bank's CEO is extensively reported in the press. But whereas there is major coverage of such statements, there is actually little scrutiny of the arguments behind them.

In Hans Christian Andersen's famous tale “The Emperor's New Clothes," two self-declared tailors offer to provide the emperor with beautiful and very special clothes. They claim that the clothes will be invisible to people who are 
(C) Copyright, Princeton University Press. No part of this book may be distributed, posted, or reproduced in any form by digital or mechanical means without prior written permission of the publisher.

stupid or unfit for their jobs. The emperor orders a full set of these special clothes. When he sends his ministers to monitor the "tailors," the ministers do not see anything, but, for fear of being considered stupid or incompetent, none of them admits this. Instead, they extol the splendors of the invisible clothes and the nonexistent fabrics of which they are made.

The emperor himself finds his new attire invisible, yet, not wanting to appear stupid or unfit to be emperor, he praises the nonexistent clothes. When he tours his capital "wearing" them, the onlookers also admire his attire, even though they do not see anything. Only when a little child shouts "The emperor has no clothes!" does everyone realize and admit that the emperor is in fact naked.

A major reason for the success of bank lobbying is that banking has a certain mystique. There is a pervasive myth that banks and banking are special and different from all other companies and industries in the economy. Anyone who questions the mystique and the claims that are made is at risk of being declared incompetent to participate in the discussion. ${ }^{6}$

Many of the claims made by leading bankers and banking experts actually have as much substance as the emperor's new clothes in Andersen's story. But most people do not challenge these claims, and the claims have an impact on policy. The specialists' façade of competence and confidence is too intimidating. Even people who know better fail to speak up. The emperor may be naked, but he continues his parade without being challenged about his attire.

Our purpose in writing this book is to demystify banking and explain the issues to widen the circle of participants in the debate. We want to encourage more people to form and to trust their opinions, to ask questions, to express doubts, and to challenge the flawed arguments that pervade the policy debate. If we are to have a healthier financial system, more people must understand the issues and influence policy.

Many have a sense that something is wrong with banking and have questions. Why did banks get into so much trouble in the crisis? Why were banks and other financial institutions bailed out? Were the bailouts necessary? Will these institutions be bailed out again if they run into trouble? Will new regulations help or hurt? Are they too tough or not tough enough? 
(C) Copyright, Princeton University Press. No part of this book may be distributed, posted, or reproduced in any form by digital or mechanical means without prior written permission of the publisher.

Leading bankers have simple answers to these questions. They may admit that mistakes were made, ${ }^{8}$ but they portray the crisis primarily as a fluke, an accident that is highly unlikely to recur in our lifetimes. ${ }^{9}$ It would be costly and wasteful, they claim, to tighten regulation to forestall an event that might happen once in a hundred years. Tighter regulation, we are warned, would interfere with what banks do to support the economy, and this would have serious "unintended consequences."10

The English classical scholar Francis Cornford wrote in 1908, "There is only one argument for doing something; the rest are arguments for doing nothing. The argument for doing something is that it is the right thing to do. Then, of course, comes the difficulty of making sure that it is right." ${ }^{\prime 1}$ He goes on to explain how "bugbears," sources of dread or false alarms, are used to raise doubts or scare. If Cornford was writing today, he would surely talk about the bugbear of "unintended consequences."

Meanwhile, politicians seem to be taken in by the lobbying. For all the outrage they expressed about the crisis, they have done little to actually address the issues involved. For example, one might infer from President Sarkozy's lashing out at bankers that France is a champion of bank regulation. But this inference would be wrong. In the bodies that try to coordinate regulatory efforts across countries, France has consistently opposed any tightening of regulation..$^{12}$ In the United States, regulations are often watered down in response to bank lobbying. For example, in passing the Dodd-Frank Act in 2010, Congress weakened the so-called Volcker Rule, which prohibits commercial banks from trading securities on their own account. Lobbying also affects the so-called rule-making process by which the regulatory bodies implement the law. ${ }^{13}$

Much of the research on banking, the financial crisis, and regulatory reform takes for granted that banks and the financial system must be as vulnerable to risks as they are, so that the failure of one bank can pull down the entire financial system. Some academic research suggests that this fragility might actually be a necessary by-product of the benefits banks provide to the economy. ${ }^{14}$ However, this work is based on assumptions under which fragility is indeed unavoidable, without assessing the relevance of the assumptions in the real world. ${ }^{15}$ 
(C) Copyright, Princeton University Press. No part of this book may be distributed, posted, or reproduced in any form by digital or mechanical means without prior written permission of the publisher.

Expanding the policy discussion beyond the circle of bankers and banking specialists is very important, because more action is urgently needed and yet has not been taken. ${ }^{16}$ The banking system is still much too fragile and dangerous. This system works for many bankers, but it exposes most of us to unnecessary and costly risks, and it distorts the economy in significant ways.

Can something be done at a reasonable cost to reduce the likelihood of banks' failing and causing a costly crisis? In one word: Yes. Will the reforms that have been decided upon achieve this aim? No. Can we have regulations that greatly increase the health and safety of the system while still allowing banks to do everything the economy needs them to do? Yes. Would we, as a society, have to sacrifice anything substantial to have a better banking system? No.

One clear direction for reform is to insist that banks and other financial institutions rely much less on borrowing to fund their investments. The reforms that have been agreed upon since 2008 are woefully insufficient in this respect, and they maintain previous approaches that have not worked well. The benefits of a more ambitious reform would be significant, whereas, contrary to the claims of leading bankers and others, the relevant costs to society would be quite small, if they existed at all.

We are not saying that stricter limits to bank borrowing are the only measures to be considered. However, these measures are important and beneficial no matter what else might be done. Reducing the excessive risks to the economy from the banking system, particularly the large distortions that result from having institutions that are "too big to fail," may well require additional measures. The key is to try to provide better incentives for market participants, and for those who design and implement regulations, so that bankers' actions will be less in conflict with the public interest.

\section{A Sampling of the Bankers' New Clothes}

A few examples will illustrate what we mean by the bankers' new clothes. Excessive borrowing by banks was identified as a major factor in the crisis of 2007-2008. Bankers themselves sometimes admit this. ${ }^{17}$ Nevertheless, the banking industry fights aggressively against tighter restrictions on bank bor- 
(C) Copyright, Princeton University Press. No part of this book may be distributed, posted, or reproduced in any form by digital or mechanical means without prior written permission of the publisher.

rowing. The constant refrain is that too much tightening of such restrictions would harm economic growth.

For example, in 2009, when negotiations about a new international agreement on banking regulation were getting under way, Josef Ackermann, then the CEO of Deutsche Bank, asserted in an interview that tighter restrictions on bank borrowing "would restrict [banks'] ability to provide loans to the rest of the economy. This reduces growth and has negative effects for all."18

This is a typical bugbear, suggesting that we must make a choice between economic growth and financial stability and that we cannot have both. After all, who would be in favor of a regulation that "reduces growth and has negative effects for all"?

Mr. Ackermann acknowledged that tighter restrictions on banks' borrowing "might increase bank safety," but he insisted that this would come at the expense of growth. He said nothing, however, about how continued financial instability and turmoil would affect growth.

The sharpest economic downturn since the Great Depression of the early 1930 occurred in the last quarter of 2008, and it was a direct result of the worldwide financial crisis that affected numerous banks and other financial institutions. The unprecedented decline in output in 2009 and the resulting loss of output have been valued in the trillions of dollars. ${ }^{19}$ The crisis has caused significant suffering for many. ${ }^{20}$ In light of these effects, warnings that greater financial stability would come at the expense of growth sound hollow. Warnings that bank lending would suffer also sound hollow. In 2008 and 2009, banks that were vulnerable because they had too much debt cut back sharply on their lending. The severe credit crunch was caused by banks' having too much debt hanging over them.

Why would restrictions on bank borrowing have any effect on bank lending at all?

One argument was given in 2010 by the British Bankers' Association, which claimed that new regulations would require U.K. banks to "hold an extra $£ 600$ billion of capital that might otherwise have been deployed as loans to businesses or households."21 To anyone who does not know what the regulation is about, this argument may look plausible. In fact, it is nonsensical and false. 
(C) Copyright, Princeton University Press. No part of this book may be distributed, posted, or reproduced in any form by digital or mechanical means without prior written permission of the publisher.

The nonsense is due to the misuse of the word capital. In the language of banking regulation, this word refers to the money the bank has received from its shareholders or owners. This is to be distinguished from the money it has borrowed. Banks use both borrowed and unborrowed money to make their loans and other investments. Unborrowed money is the money that a bank has obtained from its owners if it is a private bank or from its shareholders if it is a corporation, along with any profits it has retained. Elsewhere in the economy, this type of funding is referred to as equity. In banking, it is called capital.

Capital regulation requires that a sufficient fraction of a bank's investments or assets be funded with unborrowed money. ${ }^{22}$ This is similar to the requirement that a home buyer make a minimum down payment when buying a house. Having a minimal ratio of unborrowed funds relative to total assets is a way to limit the share of assets that is funded by borrowing. Because unborrowed funds are obtained without any promise to make specific payments at particular times, having more equity enhances the bank's ability to absorb losses on its assets.

From the statement of the British Bankers' Association, however, we would not guess that capital requirements are about how much a bank borrows. The statement makes it appear as if capital were a cash reserve-a pile of cash that banks hold that cannot be used to make loans.

In fact, capital regulation does not tell banks what to do with their funds or what they should hold. It tells banks only what portion of the funds they use must be unborrowed. Saying that new regulations would require U.K. banks to "hold an extra $£ 600$ billion of capital" is nonsensical. The implication that loans to businesses or households are automatically reduced by that $\mathfrak{£ 6}$ oo billion is false. Capital is not a rainy-day fund.

The confusion about the term bank capital is pervasive. Numerous media reports say that banks must "set aside" capital to satisfy new regulations. References to capital reserves suggest that the regulation forces banks to hold cash that sits idly in the bank's tills without being put to work in the economy. ${ }^{23} \mathrm{~A}$ bank lobbyist is quoted as saying, "A dollar in capital is one less dollar working in the economy." 24 
(C) Copyright, Princeton University Press. No part of this book may be distributed, posted, or reproduced in any form by digital or mechanical means without prior written permission of the publisher.

This confusion is insidious because it biases the debate, suggesting costs and trade-offs that do not actually exist. The trade-offs exist for reserve requirements, which call for banks to hold some fraction of their deposits in cash or in deposits with the central bank. However, capital requirements are distinct from reserve requirements and do not give rise to the same tradeoffs. Confusing the two makes it easier to argue that capital requirements prevent banks from lending when this is not actually true.

At least for banks that are organized as corporations, bank capital requirements have no automatic effect on bank lending. If capital requirements are increased, there is nothing in the regulation that would prevent these corporations from issuing additional shares and raising new funds to make any loans and investments that they might find profitable.

Banks that do not have access to the stock markets, as well as those that do, can increase their equity by retaining and reinvesting their profits. What the banks would choose to do with the funds and why they would make these choices are different matters that are obviously important. But there is no sense in which capital regulation forces banks to shrink or prevents them from making loans. Viable banks can increase their reliance on unborrowed funds without any reduction in lending.

In arguing against increased capital requirements, advocates for banks often say that capital, that is, equity, is expensive and that, if they must have more equity, their costs will increase. ${ }^{25}$ This mantra is so self-evident to banking specialists that they usually see no need to justify it. But why is it that banks hate equity so much and view it as expensive? In what exact sense is it expensive, and what does this mean for society and for policy?

We can test this argument by comparing banks to other corporations. Corporations in most industries are free to borrow as much as they want if they can find someone to make them loans. Yet there is no other sector in which corporations borrow anywhere near as much as banks do. For the vast majority of nonfinancial corporations in the United States, borrowing represents less than 50 percent of assets. Some highly successful companies do not borrow at all. ${ }^{26}$ By contrast, for banks, debt often accounts for more than 90 percent of assets. For some large European banks, the fraction is even 
(C) Copyright, Princeton University Press. No part of this book may be distributed, posted, or reproduced in any form by digital or mechanical means without prior written permission of the publisher.

higher, above 97 percent; it also was that high for some major U.S. investment banks before 2007, as well as for the mortgage giants, the Federal National Mortgage Association (Fannie Mae) and the Federal Home Loan Mortgage Corporation (Freddie Mac), which were bailed out. ${ }^{27}$ The new regulations that the banking industry complains about would still allow debt to fund 97 percent of bank assets. ${ }^{28}$

If capital is expensive, as bankers suggest, and borrowing is cheap, why doesn't this also apply to other corporations? Why don't nonbanks borrow more and economize on the supposedly expensive equity? Are these other corporations doing something wrong? For example, why doesn't Apple, which has not borrowed at all, borrow some money by issuing some debt and use the proceeds to pay its shareholders? Wouldn't this be beneficial, replacing the company's expensive equity with cheap debt? Or is there something fundamentally different about the funding costs of banks?

The business of banking is different, but bank stocks are held by the same investors, or by investors who value stocks in the same way, as those who invest in other companies. They do not look different from other stocks; all stocks allow their owners to receive dividends and sell the shares for cash at the prevailing price in the stock market. Why would bank stocks be any different from those of other corporations?

One difference that is important for bank funding costs became evident in 2008: if an important bank gets into trouble and comes close to defaulting on its debt, there is a good chance that the government or the central bank will support it to prevent default. A few corporations outside the financial sector have also benefited from government bailouts, for example, the auto industry, ${ }^{29}$ but those instances have been rare exceptions. In the financial sector, bailouts of large institutions, or of many institutions if they get into trouble at the same time, have become the rule.

If a company can count on being bailed out by the government when it cannot pay its debts and its creditors do not worry much about its defaulting, creditors will be happy to lend to the company. The company will therefore find that borrowing is cheap and, by comparison, other ways to fund investments, such as equity, are expensive. The interest that the company has to pay on its debt will not reflect its true default risk because that is partly borne by 
(C) Copyright, Princeton University Press. No part of this book may be distributed, posted, or reproduced in any form by digital or mechanical means without prior written permission of the publisher.

the taxpayer. From the perspective of the banks, therefore, borrowing is cheap. But this is true only because the costs of bank borrowing are partly borne by taxpayers.

When bank lobbyists claim that having more equity would raise their costs, they never mention the costs to taxpayers of making their borrowing cheap. At times they even deny the presence of the subsidies to their debt. ${ }^{30}$ Yet there is significant evidence that bank borrowing benefits from the prospect of taxpayer bailouts. For example, credit rating agencies sometimes assign higher ratings to bank debt than they would if the banks had no prospect of being bailed out. ${ }^{31}$ These higher ratings directly lower the interest rates at which banks can borrow. ${ }^{32}$ The value of this benefit is greater the more a bank borrows.

These are just a few examples of what we refer to as the bankers' new clothes, flawed and misleading claims that are made in discussions about banking regulation. Many of the claims resonate with basic feelings, yet they have no more substance than the emperor's fictitious clothes in Andersen's story.

This book will provide you with a framework for thinking about the issues so you can gain a better understanding of them and see flawed arguments for what they are. It does not require any expertise in or prior knowledge of economics, finance, or banking. You might think that this is not your field. However, if the discussion of banking and banking regulation is left only to those who are directly concerned, the financial system will continue to be at risk from unsafe banking, and all of us may suffer the consequences. Only pressure from the public can bring forth the necessary political will. Without public pressure and political will, we can expect little change.

Many of the bankers' new clothes that we expose in this book are related to how much banks borrow. In order to understand the issues, we first explore the impact of borrowing by individuals and companies on risk and on investments more generally. This will enable us to see where banks are similar to other companies and where they are different.

Borrowing is not the only topic of the book. Many more flawed claims are made in the debate on banking regulation. Most of these bankers' new clothes are also bugbears, warnings of unintended consequences meant to 
(C) Copyright, Princeton University Press. No part of this book may be distributed, posted, or reproduced in any form by digital or mechanical means without prior written permission of the publisher.

scare policymakers out of doing something without focusing properly on the issues or proposing how the actual problems should be solved.

For example, leading bankers often call for so-called level playing fields in regulation. ${ }^{33}$ They warn that their ability to hold their own in global competition might suffer if regulation were any stricter for them than for banks in other countries. This argument is also used by other industries, and it can succeed in weakening regulation, but it is invalid. ${ }^{34}$ A country's public policy should not be concerned about the success of its banks or other firms as such, because success that is achieved by taxpayer subsidies or by exposing the public to excessive risks-for example, the risks of pollution or of a financial crisis-is not beneficial to the economy and to society.

On the issue of how much banks should borrow, as well as how much risk they should take, there is a fundamental conflict between what is good for bankers privately and what is good for the broader economy. By having policies that encourage bank borrowing and risk taking, we paradoxically make it attractive for banks to choose levels of debt and risk that are harmful without serving any useful purpose.

Whatever else we do, imposing significant restrictions on banks' borrowing is a simple and highly cost-effective way to reduce risks to the economy without imposing any significant cost on society. Curbing excessive and harmful risk taking by bankers may require additional laws and regulations.

\section{Why Bank Safety Matters}

Why should we care so much about the safety of banks and about how much banks borrow? The more anyone borrows, the greater the likelihood that the debts cannot be paid. When this happens, most borrowers go into bankruptcy, the lenders' claims are frozen until a court has determined what they can be paid, and then, usually, the lenders are paid much less than what they are owed. ${ }^{35}$

When a borrower is a bank, the damage resulting from its defaulting on its debts can be great, affecting many beyond those directly involved with the bank. This is especially true when the bank is a systemically important financial institution like JPMorgan Chase or Deutsche Bank, with massive opera- 
(C) Copyright, Princeton University Press. No part of this book may be distributed, posted, or reproduced in any form by digital or mechanical means without prior written permission of the publisher.

tions all over the globe. ${ }^{36}$ Excessive borrowing by such banks exposes all of us to risks, costs, and inefficiencies that are entirely unnecessary.

In the run-up to the financial crisis, the debts of many large banks financed 97 percent or more of their assets. Lehman Brothers in the United States, Hypo Real Estate in Germany, Dexia in Belgium and France, and UBS in Switzerland had many hundreds of billions of dollars, euros, or Swiss francs in debt. ${ }^{37}$ Lehman Brothers filed for bankruptcy in September 2008. The other three avoided bankruptcy only because they were bailed out by their governments. ${ }^{38}$

The Lehman Brothers bankruptcy caused severe disruption and damage to the global financial system. ${ }^{39}$ Stock prices imploded, investors withdrew from money market funds, money market funds refused to renew their loans to banks, and banks stopped lending to each other. Banks furiously tried to sell assets, which further depressed prices. Within two weeks, many banks faced the prospect of default. ${ }^{40}$

To prevent a complete meltdown of the system, governments and central banks all over the world provided financial institutions with funding and with guarantees for the institutions' debts. ${ }^{41}$ These interventions stopped the decline, but the downturn in economic activity was still the sharpest since the Great Depression. ${ }^{42}$ Anton Valukas, the lawyer appointed by the bankruptcy court to investigate Lehman Brothers, put it succinctly: "Everybody got hurt. The entire economy has suffered from the fall of Lehman Brothers . . . the whole world." 43

In the fall of 2008, many financial institutions besides Lehman Brothers were also vulnerable. Ben Bernanke, chairman of the Federal Reserve, told the Financial Crisis Inquiry Commission (FCIC) that "out of maybe . . 13 of the most important financial institutions in the United States, 12 were at risk of failure within a period of a week or two." ${ }^{4}$ Some or all of the major banks in Belgium, France, Germany, Iceland, Ireland, the Netherlands, Switzerland, and the United Kingdom failed or were at significant risk of failing had their governments not bailed them out. ${ }^{45}$

Accounts of the crisis often focus on the various breakdowns of bank funding between August 2007 and October 2008. ${ }^{46}$ Much bank funding con- 
(C) Copyright, Princeton University Press. No part of this book may be distributed, posted, or reproduced in any form by digital or mechanical means without prior written permission of the publisher.

sisted of very short-term debt. Banks were therefore vulnerable to the risk that this debt would not be renewed. The deeper reason for the breakdowns, however, was that banks were highly indebted. When banks suffered losses, investors, including other financial institutions, lost confidence and cut off funding, fearing that the banks might become unable to repay their debts. ${ }^{47}$ The Lehman Brothers bankruptcy itself heightened investors' concerns by showing that even a large financial institution might not be bailed out, and therefore that default of such an institution was a real possibility. ${ }^{48}$

The problem posed by some banks being regarded as too big to fail is greater today than it was in 2008. Since then, the largest U.S. banks have become much larger. On March 31, 2012, the debt of JPMorgan Chase was valued at \$2.13 trillion and that of Bank of America at \$1.95 trillion, more than three times the debt of Lehman Brothers. The debts of the five largest banks in the United States totaled around $\$ 8$ trillion. These figures would have been even larger under the accounting rules used in Europe. ${ }^{49}$

In Europe, the largest banks are of similar size. Because European economies are smaller than that of the United States, the problem is even more serious there. Relative to the overall economy, banks are significantly larger in Europe than in the United States, especially in some of the smaller countries. ${ }^{50}$ In Ireland and Iceland before the crisis, the banking systems had become so large that, when the banks failed, these countries' economies collapsed. ${ }^{51}$

The traumatic Lehman experience has scared most governments into believing that large global banks must not be allowed to fail. Should any of these large banks get into serious difficulties, however, we may discover that they are not only too big to fail but also too big to save. There will be no good options.

The consequences of letting a large bank fail are probably more severe today than in the case of Lehman Brothers in 2008, but saving them might cripple their countries. The experiences of Ireland and Spain provide a taste of what can happen if large banking systems have to be saved by their governments. In both countries, the governments were unable to deal with their banking problems on their own, so they had to ask for support from the International Monetary Fund and from the European Union. ${ }^{52}$ 
(C) Copyright, Princeton University Press. No part of this book may be distributed, posted, or reproduced in any form by digital or mechanical means without prior written permission of the publisher.

This situation makes it all the more important to prevent scenarios in which governments must choose between letting a major institution fail or committing to an expensive bailout. One approach is to try to create mechanisms that would allow large banks to fail without disrupting the economy or requiring public support. Although useful efforts have been made in this direction, this remains a challenge for global banks. Even the best resolution mechanism is likely to be disruptive and costly. ${ }^{53}$

Whatever else might be done, significantly reducing the reliance of large banks on borrowing is the most straightforward and cost-effective approach to crisis prevention. Current and proposed regulations go in the right direction, but they are far from sufficient and have serious flaws. ${ }^{54}$ This situation reflects the success of bank lobbying and the prevalence of flawed arguments, the bankers' new clothes, in the debate. To make progress, the issues must be clarified.

The present situation is perverse. It is as if we were to subsidize the chemical industry to intentionally pollute rivers and lakes. Such subsidies would encourage additional pollution. If the industry were asked to limit the pollution, it would complain that its costs would increase. Would such complaints make us tolerate the pollution? Subsidizing banks to borrow excessively and take on so much risk that the entire banking system is threatened is just like subsidizing and encouraging companies to pollute when they have clean alternatives.

Most investments involve risks. If investments are funded by borrowing, the risks are borne not just by the borrowers but also by the lenders, and possibly by others. The borrowing itself magnifies risk, and it creates fundamental conflicts of interest that can also lead to inefficiencies. These conflicts of interest and inefficiencies explain much of what is wrong with banking and suggest what to do about it.

To understand the issues-and to see through the bankers' new clothesit is important to understand the relation between borrowing and risk. This is the subject to which we turn now. In the next two chapters we discuss the relation between borrowing and risk without a focus on banking. Then we turn to banking, risk in banking, and the implications of excessive risk for 
(C) Copyright, Princeton University Press. No part of this book may be distributed, posted, or reproduced in any form by digital or mechanical means without prior written permission of the publisher.

14 CHAPTER ONE

the financial system. This background will frame our discussion of banking regulation and the bankers' new clothes in later chapters. The discussion will also throw light on the politics of banking. Providing a better understanding of the issues and the political challenge has been our motivation in writing this book. 